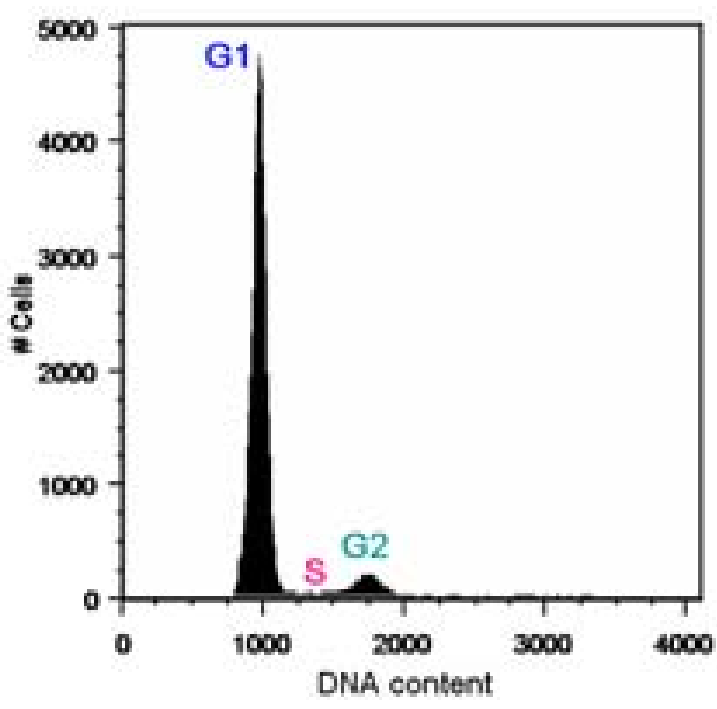

B

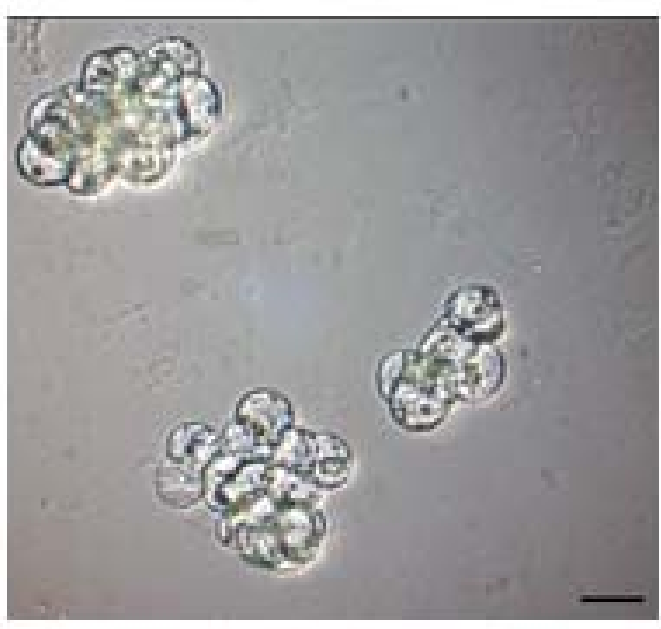

C
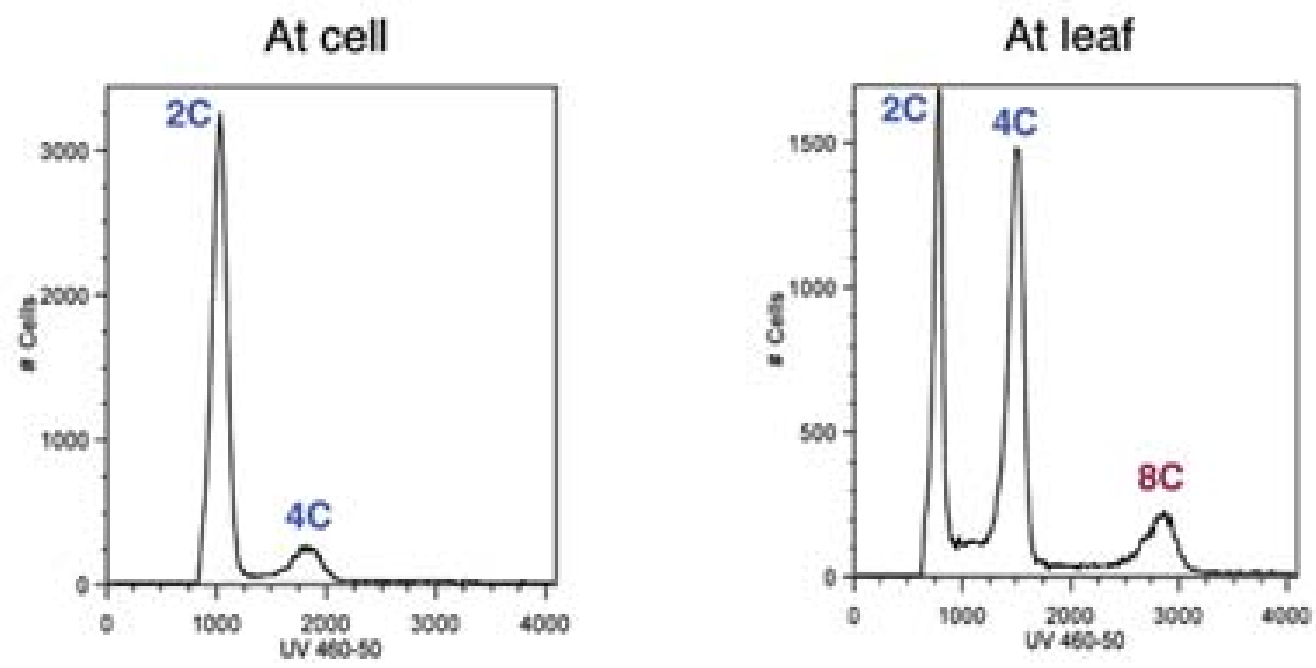

D

\title{
BrdU Incorporation
}

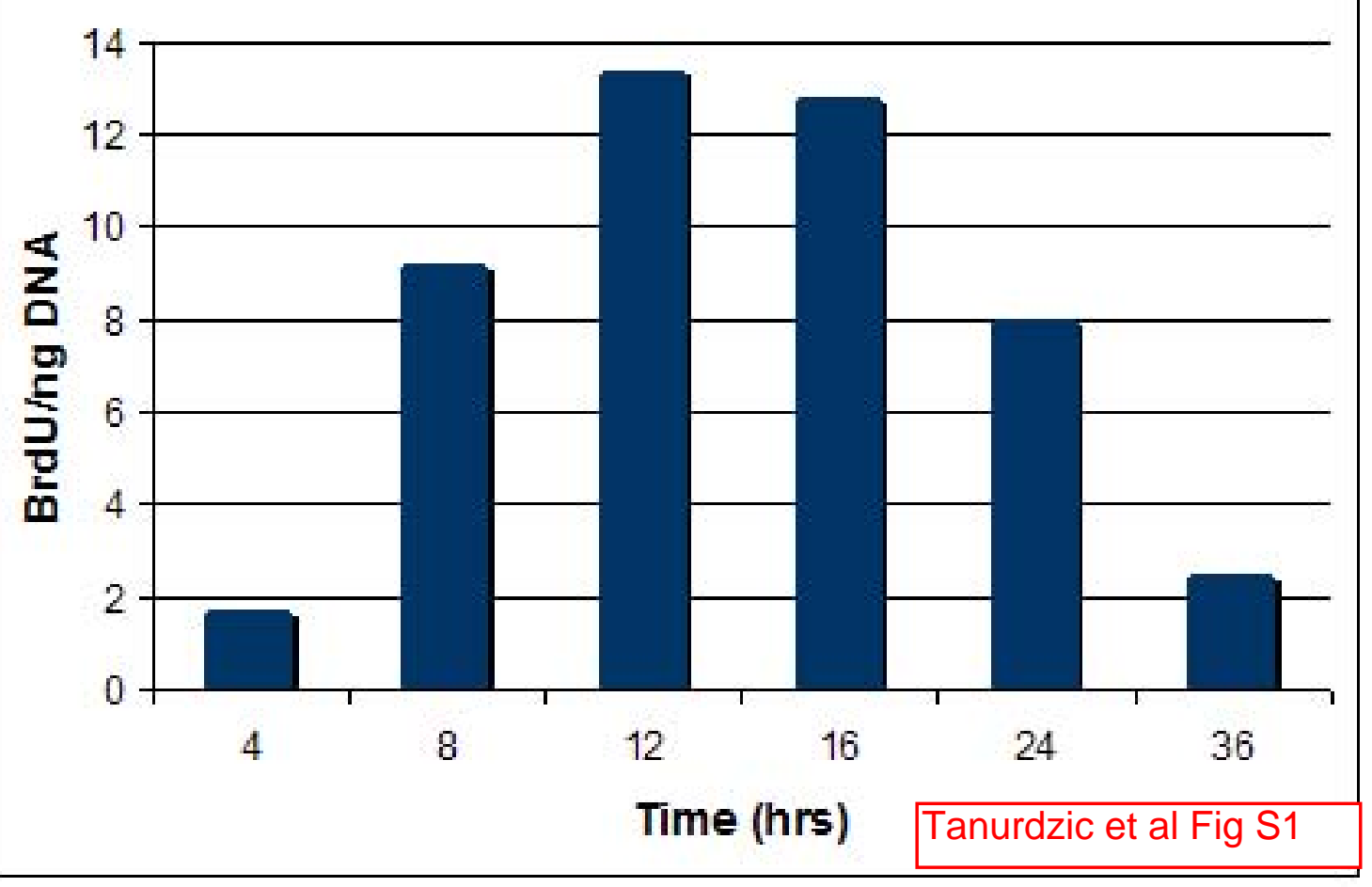

